\title{
PEMBERIAN MILKSHAKE PISANG SEBELUM LATIHAN TERHADAP KELELAHAN DAN TEKANAN DARAH ATLET SEPAK BOLA
}

\section{THE EFFECT OF BANANA MILKSHAKE BEFORE TRAINING ON FATIGUE AND BLOOD PRESSURE IN FOOTBALL ATHLETES}

\author{
Linda Ustafia ${ }^{1}$, Susi Tursilowati ${ }^{2}$, Astidio Noviardhi ${ }^{3}$ \\ ${ }^{1}$ Mahasiswa Program Studi D-IV Jurusan Gizi Poltekkes Kemenkes Semarang \\ 2,3 Dosen Jurusan Gizi Poltekkes Kemenkes Semarang
}

\section{ABSTRACT}

Background : Fatigue is affected by decreased muscle glycogen and decreased blood flow to muscle. In addition, dilation and constriction of blood vessels during exercise also affects blood pressure. Bananas are a source of carbohydrates and potassium. Carbohydrates are used to energy and potassium are used to regulate heart rate and maintain fluid and electrolyte balance. Calcium in milk can help muscle contraction during exercise.

Objective : to determine the effect of banana milkshake on fatigue and blood pressure in football athletes.

Methods : true experiment study with pre and post only control group design. Subjects of this study is 14 football athletes were randomly divided into 2 groups: the control group given banana and the treatment group given the banana milkshake. Fatigue at soccer athletes in PS Undip was measured with a harvard step test by calculating the Body efficiency index and blood pressure measured before and after the test. Data were analyzed by independent $t$-test and paired t-test.

Results : Mean Body Efficiency Index (VO2max) before treatment in treatment group $89.85 \pm 8.46$ and after treatment $92.41 \pm 9.813$ and in control group before treatment $94.45 \pm 11.596$ and after treatment $99.01 \pm 8.325$. The difference of systolic and diastolic blood pressure in treatment group before treatment was $19.43 \pm 22.44$ and $0.00 \pm 7.68$ while in control group $19.28 \pm 14.96$ and $2.71 \pm 10.68$. After treatment in treatment group 30.57 \pm 18.88 and $2.143 \pm 10,023$ while control group $13.43 \pm 18.15$ and $6.28 \pm 18.98$.

Conclusion : There is no effect of banana milkshake on fatigue and blood pressure. Bananas are more effective than banana milkshakes.

\section{ABSTRAK}

Latar Belakang : Kelelahan dipengaruhi oleh penurunan glikogen otot dan berkurangnya aliran darah ke otot. Selain itu, pelebaran dan penyempitan pembuluh darah saat olahraga juga berpengaruh terhadap tekanan darah. Pisang merupakan buah sumber karbohidrat dan kalium. Karbohidrat digunakan sebagai sumber energi dan kalium berfungsi untuk mengatur detak jantung dan menjaga keseimbangan cairan dan elektrolit. Kalsium pada susu dapat membantu kontaksi otot saat olahraga.

Tujuan : mengetahui pengaruh pemberian milkshake pisang terhadap kelelahan dan tekanan darah pada atlet sepakbola.

Metode : penelitian true experiment dengan rancangan pre dan post only control group design. Subyek penelitian 14 atlet sepak bola yang dibagi secara acak menjadi 2 kelompok yaitu kelompok kontrol yang diberikan pisang serta kelompok perlakuan yang diberi milkshake pisang. Kelelahan pada atlet sepak bola di PS Undip diukur dengan harvard step test dengan menghitung Indeks efisiensi tubuh dan tekanan darah diukur sebelum dan sesudah test tersebut. Data dianalisis dengan uji independent $t$-test dan paired $t$-test.

Hasil : Rata - rata Indeks Efisiensi Tubuh $\left(\mathrm{VO}_{2} \max \right)$ sebelum perlakuan pada kelompok perlakuan $89.85 \pm 8.46$ dan sesudah perlakuan $92.41 \pm 9.813$ dan pada kelompok kontrol sebelum perlakuan $94.45 \pm 11.596$ dan setelah perlakuan $99.01 \pm 8.325$. Selisih tekanan darah sistol dan diastol pada kelompok perlakuan sebelum perlakuan $19.43 \pm 22.44$ dan $0.00 \pm 7.68$ sedangkan pada kelompok kontrol $19.28 \pm 14.96$ dan $2.71 \pm 10.68$. Setelah perlakuan 
pada kelompok perlakuan $30.57 \pm 18.88$ dan $2.143 \pm 10.023$ sedangkan kelompok kontrol $13.43 \pm 18.15$ dan $6.28 \pm 18.98$.

Kesimpulan : Tidak ada pengaruh pemberian milkshake pisang terhadap kelelahan dan tekanan darah. Pisang lebih efektif dibandingkan dengan milkshake pisang.

\section{PENDAHULUAN}

Kelelahan atau ketidakmampuan untuk memulihkan rasa lelah merupakan problem utama yang sering ditemui atlet yang dapat menurunkan performa saat bertanding maupun berlatih ${ }^{1}$.

Sepakbola merupakan salah satu cabang olahraga yang mempunyai resiko terjadinya kelelahan. Permainan ini membutuhkan daya tahan jantung dan paru yang menggambarkan kapasitas untuk melakukan aktivitas secara terus menerus dalam waktu lama tanpa mengalami kelelahan yang berarti².

Latihan akan menyebabkan semakin kuatnya kontraksi otot jantung. Hal ini memengaruhi pelebaran dan penyempitan pembuluh darah yang kemudian berpengaruh pada tekanan darah. Semakin tinggi intensitas latihan maka denyut nadi juga semakin meningkat ${ }^{3}$.

Salah satu cara mengukur kelelahan adalah dengan pengukuran daya tahan atlet karena kelelahan berbanding terbalik dengandaya tahan ${ }^{4}$. Salah satu faktor yang mempengaruhi daya tahan adalah asupan gizi terutama karbohidrat ${ }^{5}$.

Atlet yang mengkonsumsi karbohidrat dalam jumlah yang besar dalam sehari-hari akan memilki simpanan glikogen yang relatif lebih besar. Peningkatan jumlah simpanan glikogen sebesar $25 \%$ - $100 \%$ dapatdilakukan dengan mengkonsumsi karbohidrat sebelum latihan atau pertandingankarena dapat menunda terjadinya kelelahan saat latihan atau pertandingan hingga $20 \%{ }^{6}$.

Pisang kaya akan mineral seperti kalium, magnesium, fosfor, besi dan kalsium. Karbohidrat pada pisang dapat menyediakan energi secara instan sehingga bermanfaat dalam menyediakan kebutuhan kalori sesaat ${ }^{7}$.

Karbohidrat yang dikonsumsi pada saat berolahraga diperkirakan mampu untuk mempertahankan level glukosa di dalam darah dan dapat membantu untuk menjaga tingkat pembakaran karbohidrat di dalam tubuh sehingga terjadinya kelelahan dapat dihambat hingga 30-60 menit ${ }^{6}$.

Selain karbohidrat, Kandungan kalium pada pisang juga cukup tinggi dan bermanfaat untuk mengendalikan kerja otot dan tulang sehingga mencegah terjadinya kram, keseleo dan cedera olahraga lainnya. Selain itu, kalium juga berfungsi untuk mengatur detak jantung dengan baik serta mengatur kesimbangan cairan dalam tubuh $^{8}$. Pemberian pisang 60 menit sebelum latihan sebanyak 150 gram atau 300 gram berpengaruh secara bermakna untuk mencegah terjadinya kelelahan otot pada fase aerob ${ }^{4}$.

Susu merupakan salah satu minuman yang direkomendasikan untuk pemulihan atlet. Protein susu terlarut sangat efisien untuk meningkatkan ketahanan terhadap kelelahan yang dikombinasikan dengan pelatihan ketahanan ${ }^{9}$. Kandungan kalsium yang tinggi pada susu skim juga dapat membantu dalam kontraksi otot dan transmisi saraf dan zat besi membantu dalam pengantar dan penggunaan oksigen dalam tubuh ${ }^{10}$.

Berdasarkan latar belakang diatas, peneliti tertarik melakukan penelitian tentang pengaruh pemberian milkshake pisang sebelum latihan terhadap kelelahan dan tekanan darah atlet sepak bola. Pemilihan pembuatan milkshake dikarenakan pada makanan bentuk cair seperti milkshake dapat dengan cepat meeninggalkan lambung sehingga lebih cepat diserap tubuh dan digunakan sebagai sumber energi ${ }^{11}$

Tujuan penelitian ini adalah untuk mengetahui pengaruh pemberian milkshake pisang terhadap kelelahan dan tekanan darah pada atlet sepakbola.

\section{METODE PENELITIAN}

Jenis penelitian ini adalah penelitian True Experiment dan menggunakan rancangan penelitian pre dan post test control group design. Pada penelitian ini subjek yang memenuhi kategori inklusi dikelompokkan menjadi dua yaitu kelompok perlakuan dan kelompok kontrol. Dalam penelitian kelompok perlakuan diberi milkshake pisang, sedangkan kelompok kontrol diberi pisang.

Lokasi penelitian dilakukan PS UNDIP sejak April 2017 sampai dengan Mei 2017. Subjek dalam penelitian ini adalah atlet sepakbola di PS UNDIP dengan kategori : usia 15 - 23 tahun, tidak mengkonsumsi suplemen dan tidak sedang dalam keadaan sakit atau pasca operasi. Besar sampel dihitung menggunakan rumus Lemeshow, dengan perbandingan kelompok perlakuan dan kelompok kontrol 1 : 1 maka didapatkan jumlah masingmasing 7 subjek. 
Variabel penelitian meliputi variabel bebas yaitu pemberian milkshake pisang dan variabel terikat yaitu kelelahan dan tekanan darah

Instrumen yang akan digunakan terdiri dari formulir identitas, microtoice dan timbangan injak digital untuk mengukur status gizi, tensimeter digital, dan formulir food recall 24 jam untuk mengumpulkan data asupan makan.

Untuk mengetahui perbedaan kelelahan dan tekanan darah antara kelompok perlakuan dan kelompok kontrol dilakukan analisis bivariat. Uji yang digunakan adalah uji indipendent t test pada tingkat kemaknaan 0,05. Sedangkan untuk mengetahui perbedaan kelelahan dan tekanan darah sebelum dan sesudah perlakuan dengan menggunakan uji Paired t-test dengan tingkat kemaknaan 0,05.

\section{HASIL DAN PEMBAHASAN}

Penelitian ini dilakukan di PS UNDIP terhadap atlet sepakbola yang berusia 15 - 23 tahun sejak April 2017 sampai dengan Mei 2017. Jumlah subjek yang diteliti sebanyak 14 orang yang terdiri dari kelompok perlakuan sebanyak 7 orang dan kelompok kontrol sebanyak 7 orang.

\section{KARAKTERISTIK SUBJEK}

Tabel 1. Karakteristik Subyek Penelitian

\begin{tabular}{ccccccc}
\hline Variabel & \multicolumn{2}{c}{ Mean \pm SD } & \multicolumn{2}{c}{ Maksimum } & \multicolumn{2}{c}{ Minimum } \\
& Perlakuan & Kontrol & Perlakuan & Kontrol & Perlakuan & Kontrol \\
\hline $\begin{array}{c}\text { Umur } \\
\text { (tahun) }\end{array}$ & $17.39 \pm 2.574$ & $16.24 \pm 1.968$ & 22 & 20 & 15 & 15 \\
& & & & & & \\
BB $(\mathrm{kg})$ & $58.61 \pm 5.67$ & $56.1 \pm 6.72$ & 70.30 & 64.60 & 53.60 & 45.80 \\
$\mathrm{~TB}(\mathrm{~cm})$ & $167.63 \pm 6.247$ & $165.29 \pm 6.29$ & 176.80 & 178.00 & 160.20 & 160.20 \\
$\mathrm{IMT}\left(\mathrm{kg} / \mathrm{m}^{2}\right)$ & $20.87 \pm 1.778$ & $20.49 \pm 1.64$ & 23.69 & 23.04 & 18.79 & 17.80 \\
\hline
\end{tabular}

Rata - rata umur untuk kelompok kontrol adalah 16,24 tahun dan kelompok perlakuan adalah 17,39 tahun. Untuk rata-rata berat badan dan tinggi badan kelompok kontrol adalah sebesar 56,1 kg dan $165,29 \mathrm{~cm}$ sedangkan kelompok perlakuan adalah $58.61 \mathrm{~kg}$ dan $167.63 \mathrm{~cm}$ dengan rata - rata IMT kelompok kontrol dan perlakuan masing - masing adalah 20.49 dan $20.87 \mathrm{~kg} / \mathrm{m}^{2}$.

Tabel 2. Kategori Subyek Penelitian

\begin{tabular}{lcc}
\hline \multicolumn{1}{c}{ Kategori } & $\begin{array}{c}\text { Perlakuan } \\
\mathrm{n}(\%)\end{array}$ & $\begin{array}{c}\text { Kontrol } \\
\mathrm{n}(\%)\end{array}$ \\
\hline IMT & $0(0 \%)$ & $1(14.3 \%)$ \\
Underweight & $6(85.7 \%)$ & $5(71.4 \%)$ \\
Normal & $1(14.3 \%)$ & $1(14.3 \%)$ \\
Overweight & & \\
Asupan Energi & $3(42.9 \%)$ & $5(71.4 \%)$ \\
Sangat Kurang & $4(57.1 \%)$ & $2(28.6 \%)$ \\
Kurang & & \\
Asupan Protein & $0(0 \%)$ & $1(14.3 \%)$ \\
Sangat Kurang & $4(57.1 \%)$ & $6(85.7 \%)$ \\
Kurang & $2(28.6 \%)$ & $0(0 \%)$ \\
Normal & $1(14.3 \%)$ & $0(0 \%)$ \\
Lebih & & \\
& & \\
Asupan Lemak & $3(42.9 \%)$ & $2(28.6 \%)$ \\
Sangat Kurang & $3(42.9 \%)$ & $4(57.1 \%)$ \\
Kurang & $1(14.3 \%)$ & $1(14.3 \%)$ \\
Normal & & \\
Asupan Karbohidrat & & $6(85.7 \%)$ \\
Sangat Kurang & & \\
Kurang & &
\end{tabular}

Sampel pada penelitian ini rata - rata memiliki IMT normal yaitu $85,7 \%$ pada kelompok perlakuan dan $71,4 \%$ pada kelompok kontrol. Sedangkan untuk asupan energi masih dalam kategori kurang dan sangat kurang pada kedua kelompok. Untuk asupan protein pada pada kelompok kontrol masih dalam kategori kurang dan sangat kurang sedangkan pada kelompok perlakuan $57,1 \%$ asupan protein kurang, $28,6 \%$ normal dan $14,3 \%$ asupan protein sampel lebih. Untuk asupan lemak juga masih dalam kategori kurang dan sangat kurang pada kedua kelompok, hanya $14,3 \%$ yang mempunyai asupan lemak kurang pada kedua kelompok. Sedangkan untuk asupan karbohidrat masih dalam kategori kurang dan sangat kurang pada semua sampel.

\section{KELELAHAN PADA ATLET}

Tabel. 3. Kategori Kelelahan Atlet

\begin{tabular}{lcc}
\hline \multicolumn{1}{c}{ Kategori Kelelahan } & Perlakuan & Kontrol \\
& $\mathrm{n}(\%)$ & $\mathrm{n}(\%)$ \\
\hline Kelelahan Rendah & $7(100 \%)$ & $6(85.7 \%)$ \\
Kelelahan Sedang & $0(0 \%)$ & $1(14.3 \%)$ \\
TOTAL & $7(100 \%)$ & $7(100 \%)$ \\
\hline
\end{tabular}

Kelelahan atlet pada kelompok perlakuan semuanya termasuk dalam kategori kelelahan yang rendah, sedangkan pada kelompok kontrol sebanyak 6 orang (85.7\%) termasuk kategori kelelahan rendah dan 1 orang (14.3\%) termasuk kategori kelelahan sedang.

Tabel 4. Analisis Asupan dengan $\mathrm{VO}_{2} \max$

\begin{tabular}{lcc}
\hline \multirow{2}{*}{\multicolumn{1}{c}{ Asupan }} & \multicolumn{2}{c}{$\mathrm{VO}_{2} \max$} \\
\cline { 2 - 3 } & $p$ value & Pearson Correlation \\
\hline Asupan Energi & 0.275 & 0.314 \\
Asupan Protein & 0.470 & 0.211 \\
Asupan Lemak & 0.211 & 0.356 \\
Asupan Karbohidrat & 0.651 & 0.133 \\
\hline
\end{tabular}


Berdasarkan hasil uji korelasi pearson, asupan energi, protein, lemak dan karbohidrat tidak mempunyai hubungan yang signifikan dengan $\mathrm{VO}_{2}$ max atlet tetapi ada korelasi yang positif antara asupan dengan $\mathrm{VO}_{2} \max$. Artinya semakin tinggi asupan maka $\mathrm{VO}_{2}$ max atlet semakin tinggi pula yang berarti kelelahan pada atlet juga menurun.

Tabel 5. Hasil Uji Analisis Kelelahan dengan Indikator Indeks Efisiensi Tubuh ( $\left.\mathrm{VO}_{2} \mathrm{max}\right)$

\begin{tabular}{lccc}
\hline \multicolumn{1}{c}{ Indeks Efisiensi } & \multicolumn{2}{c}{ Mean $\pm \mathrm{SD}$} & $p$ value \\
\multicolumn{1}{c}{ Tubuh $\left(\mathrm{VO}_{2}\right.$ max $)$} & Perlakuan & Kontrol & \\
\hline Sebelum Perlakuan & $89.85 \pm 8.46$ & $94.45 \pm 11.596$ & $0.414^{\mathrm{a}}$ \\
Setelah Perlakuan & $92.41 \pm 9.813$ & $99.01 \pm 8.325$ & $0.415^{\mathrm{a}}$ \\
Selisih & $2.55 \pm 5.21$ & $4.56 \pm 6.47$ & $0.534^{\mathrm{a}}$ \\
$p$ value & $0.242^{\mathrm{b}}$ & $0.111^{\mathrm{b}}$ & \\
\hline
\end{tabular}

$a=U j i$ Indipendent $t$-test $b=U j i$ Paired $t$-test

Berdasarkan hasil uji tersebut didapatkan hasil signifikansi $p>0.05$ yang berarti tidak ada pengaruh pemberian milkshake pisang terhadap kelelahan pada atlet sepakbola Kelelahan diukur dengan metode harvard step test dengan melihat nilai Indeks Efisiensi Tubuh. Semakin tinggi Indeks Efisiensi Tubuh maka kelelahan semakin rendah.

Penurunan tingkat kelelahan lebih banyak pada kelompok kontrol yang diberi pisang yaitu sebesar 4,56 sedangkan kelompok perlakuan turun sebesar 2.55. Meskipun terdapat kenaikan indeks efisiensi tubuh namun berdasarkan uji paired test didapatkan hasil $p>0.05$ baik pada kelompok kontrol maupun kelompok perlakuan yang berarti tidak ada pengaruh yang signifikan sebelum dengan sesudah diberikan milkshake pisang pada kelompok perlakuan maupun diberikan pisang pada kelompok kontrol. Pisang dapat mengatasi kelelahan pada atlet $^{4}$. Jadi milkshake pisang juga menjadi inovasi makanan cair bagi atlet tetapi konsumsi pisang sebelum latihan lebih efektif dalam menurunkan kelelahan pada atlet sepakbola.

Harvard step test efektif untuk mengukur kelelahan yang didapat dari nilai $\mathrm{VO}_{2} \max$ atlet dengan melihat indeks efisiensi tubuh atlet ${ }^{12}$. Faktor - faktor yang mempengaruhi daya tahan antara lain keturunan, Usia, Jenis kelamin, aktivitas fisik, status gizi dan asupan gizi.

Di dalam dunia olahraga, sebuah prestasi dan kebugaran dapat diraih tidak hanya dengan bakat atau asupan nutrisi namun program pelatihan yang tepat juga akan memberikan pengaruh positif terhadap seorang atlet ${ }^{6}$. Atlet membutuhkan kebugaran jasmani yang baik agar tidak cepat mengalami kelelahan selama berolahraga ${ }^{13}$. Latihan olahraga aerobik teratur dengan frekuensi latihan tiga sampai lima kali setiap minggu, intensitas latihan $60-80 \%$ dari denyut jantung maksimal, dan durasi latihan 20 - 60 menit mengakibatkan aliran darah menjadi lancar dan mempercepat pembuangan zat-zat sisa metabolisme sehingga pemulihan berlangsung dengan cepat, dan seseorang dapat memperlambat terjadinya kelelahan setelah berolahraga ${ }^{14}$.

Asupan gizi merupakan salah satu faktor yang mempengaruhi kelelahan. Dari hasil penelitian ini, terdapat korelasi yang positif antara asupan dengan $\mathrm{VO}_{2}$ max dimana semakin tinggi asupan energi, protein, lemak dan karbohidrat maka semakin tinggi nilai $\mathrm{VO}_{2}$ max yang artinya semakin rendah juga kelelahan pada atlet tersebut.

Pisang adalah salah satu buah yang sangat dianjurkan untuk atlet. Pisang dapat digunakan untuk menggantikan fungsi minuman berkarbohidrat $6 \%$. Cadangan energi yang cukup pada saat melakukan olahraga, terutama olahraga dengan durasi lama, dapat mencegah terjadinya kelelahan $^{15}$

Kalium berfungsi antara lain untuk menjaga keseimbangan air di dalam tubuh ${ }^{16}$. Selain itu, kalium juga baik untuk mencegah kelelahan. Sebuah studi menyatakan bahwa peningkatan aktivitas $\mathrm{Na}+, \mathrm{K}+$, dan ATPase selama olahraga dapat menstabilkan konsentrasi natrium dan kalium pada membran sehingga dapat mencegah terjadinya kelelahan ${ }^{17}$. Pisang juga baik untuk atlet karena kadar kalium yang tinggi untuk mencegah kram otot ${ }^{18}$.

Pada penelitian ini tidak ada perbedaan antara pemberian pisang dengan milkshake pisang tetapi ada penurunan kelelahan pada kedua kelompok tetapi lebih efektif pada kelompok yang diberikan pisang. Pada milkshake pisang selain buah pisang sendiri terdapat penambahan susu pada pembuatannya untuk menambah cita rasa pada milkshake. Susu yang digunakan adalah susu skim.

Susu merupakan salah satu minuman yang direkomendasikan untuk pemulihan atlet. Susu dapat membantu mengurangi kerusakan otot, meningkatkan pemulihan otot, meningkatkan kemampuan tubuh untuk pembentukan otot dan dapat memulihkan rehidrasi pada saat latihan ${ }^{19}$. Pemberian susu rendah lemak dapat meningkatkan nilai $\mathrm{VO}_{2}$ max dan jarak tempuh lari yang lebih baik dibandingkan dengan pemberian minuman olahraga komersial ${ }^{10}$.

Pemberian milkshake pisang 1 jam sebelum latihan menurunkan kelelahan tetapi pada beberapa sampel ada yang mengalami kram perut. Kram perut bisa disebabkan karena rentang waktu makan yang terlalu singkat. Rentang waktu yang terlalu singkat antara makan dan olahraga menyebabkan sistem pencernaan bekerja sangat keras dalam mencerna makanan. Dalam proses mencerna makanan ini, sistem pencernaan 
membutuhkan distribusi aliran darah yang cukup agar dapat bekerja dengan optimal.Saat rentang waktu makan terlalu dekat dengan aktivitas olahraga menyebabkan distribusi aliran darah tetap difokuskan kepada kelompok otot yang sedang aktif melakukan aktivitas olahraga, sedangkan pada lambung jumlah aliran darah dikurangi. Tanpa suplai darah maka otot - otot perut akan kekurangan oksigen ${ }^{20}$. Milkshake pisang bisa efektif bila diberikan 2 jam sebelum latihan.

Berdasarkan hasil penelitian, pada kelompok kontrol dengan pemberian pisang lebih efektif dibandingkan dengan kelompok perlakuan dengan pemberian milkshake pisang tetapi keduanya tidak ada perbedaan yang signifikan terhadap kelelahan.

\section{TEKANAN DARAH}

Tabel 6. Hasil Tekanan Darah

\begin{tabular}{|c|c|c|c|c|c|c|c|}
\hline & & & & Mean $\pm S$ & & & \\
\hline & & Perl: & kuan & & & trol & \\
\hline & & Pre & Post & Selisih & Pre & Post & Selisih \\
\hline TD & Sebelu & $124.71 \pm 15.8$ & $144.14 \pm 22.44$ & $19.43 \pm 22.44$ & $127.00 \pm 6.37$ & $146.29 \pm 16.9$ & $19.28 \pm 14.96$ \\
\hline Sistol & Setelah & $128.14 \pm 16.5$ & $158.71 \pm 10.64$ & $30.57 \pm 18.88$ & $123.71 \pm 9.76$ & $137.14 \pm 20.46$ & $13.43 \pm 18.15$ \\
\hline TD & Sebelu & $75.57 \pm 11.9$ & $75.57 \pm 14.729$ & $0.00 \pm 7.68$ & $76.43 \pm 9.09$ & $79.14 \pm 6.517$ & $2.71 \pm 10.68$ \\
\hline Diastol & Setelah & $76.14 \pm 13.1$ & $78.28 \pm 14.53$ & $2.143 \pm 10.02$ & $76.71 \pm 13.09$ & $83.00 \pm 16.81$ & $6.28 \pm 18.98$ \\
\hline
\end{tabular}

Berdasarkan hasil penelitian, tekanan darah sistol sebelum perlakuan pada kelompok perlakuan mengalami kenaikan sebesar $19.43 \pm$ $22.44 \mathrm{mmHg}$ dari $124.71 \pm 15.84 \mathrm{mmHg}$ menjadi $144.14 \pm 22.44 \mathrm{mmHg}$. Sedangkan pada kelompok kontrol mengalami kenaikan sebesar 19.28 \pm 14.96 $\mathrm{mmHg}$ dari $127.00 \pm 6.377 \mathrm{mmHg}$ menjadi $146.29 \pm$ $16.978 \mathrm{mmHg}$.Tekanan darah diastol sebelum perlakuan pada kelompok perlakuan tidak mengalami kenaikan. Sedangkan pada kelompok kontrol mengalami kenaikan sebesar $2.71 \pm 10.68$ $\mathrm{mmHg}$ dari $76.43 \pm 9.09 \mathrm{mmHg}$ menjadi $79.14 \pm$ $6.517 \mathrm{mmHg}$.

\section{Tabel 7. Hasil Uji Analisis Tekanan Darah}

\begin{tabular}{lccc}
\hline \multicolumn{1}{c}{ Selisih } & \multicolumn{2}{c}{ Mean \pm SD } & $p$ value \\
\hline Tekanan Darah Sistol & & & \\
Sebelum Perlakuan & $19.43 \pm 22.44$ & $19.28 \pm 14.96$ & $0.989^{\mathrm{a}}$ \\
Setelah Perlakuan & $30.57 \pm 18.88$ & $13.43 \pm 18.15$ & $0.109^{\mathrm{a}}$ \\
Selisih & 11.14 & -5.85 & $0.269^{\mathrm{a}}$ \\
$p$ value & $0.412^{\mathrm{b}}$ & $0.426^{\mathrm{b}}$ & \\
& & & \\
Tekanan Darah Diastol & & & \\
Sebelum Perlakuan & $0.00 \pm 7.68$ & $2.71 \pm 10.68$ & $0.595^{\mathrm{a}}$ \\
Setelah Perlakuan & $2.143 \pm 10.023$ & $6.28 \pm 18.98$ & $0.619^{\mathrm{a}}$ \\
Selisih & 2.14 & 3.57 & $0.891^{\mathrm{a}}$ \\
$p$ value & $0.555^{\mathrm{b}}$ & $0.724^{\mathrm{b}}$ & \\
\hline
\end{tabular}

$a=U j i$ Indipendent $t$-test $b=U j i$ Paired t-test
Dari hasil penelitian terhadap atlet sepakbola disimpulkan bahwa tidak ada pengaruh pemberian milkshake pisang terhadap tekanan darah pada atlet sepak bola $(p<0.05)$. Untuk tekanan darah mengalami kenaikan kecuali tekanan darah sistol pada kelompok kontrol. Ini berarti pada kelompok perlakuan dengan pemberian milkshake pisang dapat menurunkan kelelahan tetapi tidak efektif untuk mengurangi selisih tekanan darah saat latihan. Pada kelompok kontrol yang diberikan pisang lebih efektif untuk menurunkan kelelahan dan tekanan darah sistol, tetapi ada kenaikan tekanan darah diastol. Berdasarkan hasil uji paired t-test, tidak ada pengaruh yang signifikan sebelum dan sesudah perlakuan tekanan darah $(p>0.05)$.

Meningkatnya hormon epinefrin saat latihan akan menyebabkan semakin kuatnya kontraksi otot jantung. Meskipun demikian tekanan sistole tidak langsung membubung tinggi, karena pengaruh epinefrin pada pembuluh darah dapat menyebabkan pelebaran (dilatasi). Pelebaran pembuluh darah akan sangat tergantung kondisinya. Jika pembuluh sudah mengalami pengerakan (arteriosklerosis) akan menjadi kaku, tidak elastis, sehingga pelebaran akan terbatas. Dengan demikian kenaikan tekanan darah saat latihan akan dapat terjadi. Peningkatan pelebaran pembuluh darah saat latihan juga disebabkan karena meningkatnya suhu tubuh. Banyaknya keringat yang keluar akan menyebabkan plasma darah keluar, volume darah menurun, sehingga tekanan darah tidak naik berlebihan ${ }^{21}$.

Intensitas latihan atlet juga mempengaruhi tekanan darah atlet. Berdasarkan sebuah penelitian menyimpulkan bahwa kelompok yang diberikan perlakuan olahraga aerobik terpogram dijumpai penurunan tekanan darah sistol yang bermakna ${ }^{22}$. Selain itu, Latihan fisik akan memberikan pengaruh yang baik terhadap berbagai macam sistem yang bekerja di dalam tubuh, salah satunya adalah sistem kardiovaskuler, dimana dengan latihan fisik yang benar dan teratur akan terjadi efisiensi kerja jantung. Efisiensi kerja jantung ataupun kemampuan jantung akan meningkat sesuai dengan perubahan-perubahan yang terjadi. Hal tersebut dapat berupa perubahan pada frekuensi jantung, isi sekuncup, dan curah jantung ${ }^{23}$.

Pada kelompok yang diberikan milkshake pisang terdapat kenaikan selisih tekanan darah, kemungkinan yang disebabkan karena adanya tambahan susu skim dimana pada susu skim menurut nutry survey mengandung natrium sebanyak $546 \mathrm{mg} / 100 \mathrm{gr}$ susu skim. Maka dalam milkshake pisang yang diberikan susu skim $40 \mathrm{gr}$ mengandung sekitar $218,4 \mathrm{mg}$. Natrium pada susu 
skim inilah yang dapat mengakibatkan adanya kenaikan selisih tekanan darah pada setelah pemberian perlakuan. Penelitian Kamso $(2000)^{24}$ menemukan adanya hubungan yang signifikan antara asupan natrium dengan tekanan darah. Tetapi natrium ini diperlukan untuk pemulihan setelah latihan akibat dari banyaknya keringat yang keluar akibat latihan.

Susu merupakan salah satu minuman untuk pemulihan rehidrasi ${ }^{19}$. Dalam susu skim selain mengandung natrium juga mengandung $\mathrm{Ca}$ sebanyak $1292.0 \mathrm{mg}$, dan kalium 1743,0 mg. Natrium merupakan mineral utama di dalam plasma darah sedangkan kalium adalah mineral utama di dalam sel. Peran mineral ini adalah untuk mempertahankan pertukaran zat gizi dan produk sisa metabolisme antara sel dengan cairan ekstrasel sedangkan kalsium dibutuhkan untuk kontraksi otot, transmisi impuls, mengaktifkan enzim, pembekuan darah dan pergerakan cairan melewati membran plasma ${ }^{25}$.

Pada saat latihan keringat dapat keluar hingga 0,5-2 liter. Dalam keringat selain air terlarut $\mathrm{Na}, \mathrm{K}, \mathrm{Mg}, \mathrm{Ca}^{21}$. Keringat adalah cairan hipotonik yang berisi natrium dan klorida. Kandungan natrium pada cairan keringat orang normal rerata $50 \mathrm{mEq} / \mathrm{L}$. Jumlah pengeluaran keringat akan meningkat sebanding dengan lamanya periode terpapar pada lingkungan yang panas, latihan fisik dan demam ${ }^{26}$. Susu skim bisa dijadikan minuman pemulihan setelah pertandingan atau latihan karena mengandung $\mathrm{Na}, \mathrm{K}$, dan $\mathrm{Ca}$ yang dapat menggantikan mineral tersebut yang hilang melalui keringat saat latihan atau bertanding.

Berdasarkan hasil penelitian, pada kelompok kontrol dengan pemberian pisang lebih efektif dibandingkan dengan kelompok perlakuan dengan pemberian milkshake pisang tetapi keduanya tidak ada perbedaan yang signifikan terhadap tekanan darah

\section{KESIMPULAN DAN SARAN}

\section{KESIMPULAN}

Berdasarkan peneliltian yang dilakukan dapat disimpulkan bahwa :

1. Terdapat penurunan kelelahan pada atlet baik kelompok perlakuan yaitu sebesar $2.55 \pm 5.21$ dan pada kelompok kontrol sebesar $4.56 \pm$ 6.47.

2. Selisih tekanan darah sistol pada kelompok perlakuan mengalami peningkatan sebesar $11.14 \pm 33.48 \mathrm{mmHg}$ sedangkan kelompok kontrol mengalami penurunan $-5.85 \pm 18.13$
mmHg. Untuk Selisih Tekanan Darah Diastol mengalami peningkatan pada kedua kelompok yaitu sebesar $2.14 \pm 9.08 \mathrm{mmHg}$ pada kelompok perlakuan dan $3.57 \pm 25.48 \mathrm{mmHg}$ pada kelompok kontrol.

3. Tidak ada pengaruh pemberian milkshake pisang terhadap kelelahan pada atlet sepakbola. Penurunan kelelahan lebih efektif pada kelompok kontrol yang diberikan pisang

4. Tidak ada pengaruh pemberian milkshake pisang terhadap tekanan darah pada atlet sepakbola. Pisang lebih efektif untuk menurunkan tekanan darah sistol setelah berolahraga.

\section{SARAN}

1. Bagi Atlet : Atlet dapat mengkonsumsi snack sebelum bertanding atau latihan karena dapat menjaga performa atlet. Salah satu snack yag dianjurkan adalah buah pisang.

2. Bagi penyelenggara makanan atlet : memperhatikan pola makan atlet agar konsumsi atlet dapat mencukupi kebutuhan serta pemberian edukasi kepada atlet perlu dilakukan karena terlihat dari asupan atlet banyak yang termaksuk dalam kategori sangat kurang.

3. Untuk Penelitian selanjutnya : Penelitian dilakukan pada subyek yang lebih banyak dan perlakuan bisa dilakukan lebih dari 1 kali untuk hasil yang lebih akurat.

\section{DAFTAR PUSTAKA}

1. Departemen Kesehatan dan Kesejahteraan Sosial RI. 2000. Pedoman Pelatihan Gizi Olahraga untuk Prestasi. Jakarta : Direktorat Jenderal Kesehatan Masyarakat

2. Supriyono . 2012 . Mempersiapkan Makanan Bagi Atlet Sepakbola. http://gizi.depkes.go.id/mempersiapkanmakanan-bagi-atlet-sepak-bola . 18 maret 2017

3. Penggalih, M.H., Hardiyanti, Marina., dan Sani, F.I . 2015. "Perbedaan Perubahan Tekanan Darah dan Denyut Jantung pada Berbagai Intensitas Latihan Atlet Balap Sepeda," Jurnal Keolahragaan volume 3 nomor 2

4. Rianti, C.R . 2014. "Pengaruh Pemberian Pisang (Musa paradisiaca) Terhadap Kelelahan Otot Aerob pada Atlet Sepak Takraw" Skripsi. Semarang : Fakultas Kedokteran Universitas Diponegoro

5. Mardian, Fadli. 2016. "Perbandingan 
Efektivitas Pemberian Minuman Isotonik dan Jus Pisang terhadap Daya Tahan Otot Selama Aktivitas Lari 30 Menit" Skripsi. Semarang : Fakultas Kedokteran Universitas Diponegoro

6. Irawan, M.A . 2007. "Nutrisi, Energi \& Performa Olahraga," Sports Science Brief. www.pssplab.com

7. Prabawati, S, Suyanti dan Setyabudi, D.A . 2008. "Teknologi Pascapanen dan Teknik Pengolahan Buah Pisang," Balai Penelitian dan Pengembangan Pertanian

8. Ramayulis, Rita. 2013. Jus Super Ajaib. Jakarta : Penebar Plus

9. Babault, N., Deley, G., Le Ruyet, P., Morgan, F., \& Allaert, F. A. (2014). Effects of soluble milk protein or casein supplementation on muscle fatigue following resistance training program: a randomized, double-blind, and placebocontrolled study. Journal of the International Society of Sports Nutrition, 11(1), 36. https://doi.org/10.1186/1550-2783-11-36

10. Kameswara, Iqbal . 2014. "Perbedaan Nilai $\mathrm{VO}_{2}$ max dan Jarak Tempuh Lari antara Pemberian Susu Rendah Lemak dan Minuman Olahraga Komersial pada Atlet Sepak Bola" Skripsi. Semarang : Fakultas Kedokteran Universitas Diponegoro

11. Irianto, D.P. 2007. Panduan Gizi Lengkap Keluarga dan Olahragawan. Yogyakarta : Penerbit Andi

12. Haryono, Sri. 2014. Evaluasi Olahraga I. Semarang : Fakultas IImu Keolahragaan universitas Negeri Semarang

13. Stolen, T., Chamri, K., Costagna, C., Wisloff U. 2005. Physiology of soccer : an update. Sport Med ; 35 (6) : 501 -36

14. Chrisly, M. Djon, W. Shane, H. 2015. Manfaat Latihan Olahraga Aerobik terhadap Kebugaran Fisik Manusia. Jurnal E-Biomedik (Ebm), Volume 3, Nomor 1

15. Nieman DC, Gillit ND, Henson DA, Sha W, Shanely RA, Knab AM, et al. 2012. Bananas as an Energy Source during Exercise: a Metabolomics Approach. PloSONE 7(5): e37479. doi:10.1371/journal.pone.0037479

16. Suyanti. Supriyadi, A. 2008. Pisang, Budi Daya, Pengolahan, dan prospek Dasar. Jakarta : Penebar Swadaya

17. Michael J. McKenna, Jens Bangsbo and Jean Marc Renaud. 2007. "Muscle $\mathrm{K}^{+}, \mathrm{Na}^{+}$, and $\mathrm{Cl}^{-}$ Disturbances and $\mathrm{Na}^{+} \mathrm{K}^{+}$pump inactivation : implications for fatigue," J Appl Physiol 104: 288-295

18. World Health Foods. 2005. Bananas. http://www.whfoods.com. 13 maret 2017

19. National Dairy Council. 2010. “Milk : Nature's
Sports Drinks"

20. Ashadi, Kunjung. 2014. "Implementasi Fisiologi Olahraga pada Olahraga Prestasi". Surabaya : Fakultas IImu Keolahragaan Universitas Negeri Surabaya

21. Pranatahadi, Sebastianus. 2009. Fisiologi Latihan.

http://staff.uny.ac.id/sites/default/files/pendi dikan/Drs.\%20Sebastianus\%20Pranatahadi,\% 20M.Kes./Fisiologi\%20Latihan.pdf . 2 Maret 2017

22. Candra, A., Rusip, G., Machrina. Y. 2016. Pengaruh Latihan Aerobik Intensitas Ringan dan Sedang terhadap Kelelahan Otot (Muscle Fatique) Atlet Sepakbola. Medan : Jurnak Kedokteran dan Kesehatan Volume 3, Nomor $1: 333-339$

23. Daenuri, A. 1999. Pengaruh Latihan terprogram terhadap perubahan frekuensi jantung pada siswa sekolah sepak bola tugu muda semarang usia 10-14 tahun. Semarang: Fakultas Kedokteran UNDIP,

24. Kamso, S. 2000. Nutritional Aspects Of Hypertension In The Indonesia Elderky: A Community Study In 6 Big Cities. Fakultas Kesehatan Masyarakat Universitas Indonesia

25. Ilyas, E. 2007. Nutrisi pada Atlet. Academia.edu

26. Yaswir, R dan Ira, Ferawati. 2012. "Fisiologi dan Gangguan Keseimbangan Natrium, Kalium dan Klorida serta pemeriksaan Laboratorium". Jurnal Kesehatan Andalas, 1(2) 